\title{
Exposure to Interferon $\gamma$ Decreases Levels and Activity of Key Cell Cycle Proteins Resulting in Severe Growth Arrest of the Human Non-Transformed Cell Line, WISH
}

\author{
Surabhi Vashistha and Parthasarathi Ajitkumar* \\ Department of Microbiology and Cell Biology, Indian Institute of Science, Bangalore - 560012, Karnataka, India
}

\begin{abstract}
Interferon $\gamma($ IFN $\gamma)$, a potent inhibitor of proliferation, inducer of apoptosis, and an immune modulator of mammalian cells, has been used as an anticancer agent in cancer therapy. Several molecular mechanisms, depending upon the differences in the lineage of transformed cell targets, have been elucidated for the growth inhibition or apoptosis of target cancer cells by IFN $\gamma$. However, its mechanism of action on normal cells needs to be understood from the point of view of: (i) The effect of IFN $\gamma$ on non-transformed cell line and (ii) The side effect of interferon therapy on normal cells in cancer patients. Using the non-transformed cell line, human foetal epithelial cell line (WISH), our earlier studies had shown that IFN $\gamma$ detains cells at a point prior to the activation step of cyclin dependent kinase 2 (CDK2) in the G1 phase of cell cycle. In the present study, we identified significant reduction in the levels and/or activity of cyclin E-CDK2, CDC25A phosphatase, cyclin $\mathrm{H}$, cyclin $\mathrm{E}$, cyclin $\mathrm{D}, \mathrm{p} 21$ and $\mathrm{p} 27$. The drastic decrease in the levels and/or activity of cyclin $\mathrm{E}$ and/or of cyclin E-CDK2 complex might have caused growth arrest of WISH cells by IFN $\gamma$.
\end{abstract}

Keywords: Interferon $\gamma$; WISH; Cell cycle; Cyclin dependent kinase 2; Cyclin E; Proliferation; Growth inhibition

Abbreviations: IFN: Interferon; CDK2: Cyclin Dependent Kinase 2; DMEM: Dulbecco's Modified Eagle's Medium; IRF1: Interferon Regulatory Factor 1; EDTA: Ethylene Diamine Tetra Acetic acid; pNPP: Para-Nitrophenyl Phosphate; pNp: Para-Nitrophenol; STAT1 $\alpha$ : Signal Transducer and Activator of Transcription $1 \alpha$

\section{Introduction}

Interferon (IFN $\gamma$ ) is a potent inhibitor of growth of mammalian cells (Pestka et al., 1987). Growth inhibition is found to be dependent on the activity of phosphorylated species of the latent cytoplasmic transcription factor STAT1 $\alpha$ (Darnell et al., 1994; Bromberg et al., 1996). It is believed that the IFN effects growth arrest through cellular functions of gene products, whose synthesis is induced or repressed by the IFN. The molecular changes include reduction in the activity of cyclin dependent kinase 2 (CDK2) in mouse embryonic fibroblasts (Bromberg et al., 1996), induction of expression of CDK2 inhibitor p21 in A431 cells (Chin et al., 1996), in glioblastoma cell lines T98G, SNB-19 and U-373 (Kominsky et al., 1998), in macrophages (Xaus et al., 1999) and in breast carcinoma MCF7 cells (Gooch et al., 2000), inhibition of cyclin A gene transcription in vascular smooth muscle cells (Sibinga et al., 1999), repression of cdk2 gene expression by the interference of interferon regulatory factor 1 (IRF1) with SP1dependent transcriptional activation of cdk2 promoter (Xie et al., 2003), hyperphosphorylation of retinoblastoma protein in mammary epithelial cells (Harvat and Jetten, 1996), and reduction in thymidine incorporation in WISH cells (Aharon et al., 2002). IFN $\gamma$ has also been found to induce or sensitise target cells to apoptosis through the induction of caspase 8 by IRF1 in Ewing tumor, neuroblastoma or medulloblastoma (Fulda and Debatin, 2002) or by downregulating the levels of p21 in human hepatocellular carcinoma cells (Detjen et al., 2003). On the contrary, IFN $\gamma$ induces $p 21$, brings about growth arrest and prevents apoptosis in macrophage cells (Xaus et al., 1999).

These specific molecular changes have been suggested to be the reasons for the growth inhibition or apoptosis, or otherwise, brought about by the IFN in the respective target cell systems. The molecular changes accompanying IFN $\gamma$-induced growth arrest and apoptosis have been found to be different in different target cell systems. All these studies have been performed using transformed cancer cell lines of different lineages and hence the mode of growth inhibition or apoptosis has been different. Therefore, it is necessary to understand the effect of IFN $\gamma$ on non-transformed cells (cell lines) and to study the side effects of IFN $\gamma$ in IFN $\gamma$-mediated cancer therapy on normal cells in cancer patients. For this purpose, the non-transformed human cell line, WISH, was chosen. In this regard, we had earlier reported that WISH cells, which are growth-arrested by IFN $\gamma$, are detained at a point prior to DNA synthesis in a reversible manner and that the IFN acts within the first $11 \mathrm{hrs}$ in G1 phase of the cell cycle (Supriya et al., 1998; Vashistha et al., 2007). These observations prompted us to examine the levels and/or activity of G1- and G1/S-specific cell cycle proteins. Thus in this study, we report identification of molecular changes in the levels and/or activities of G1 phase-specific and G1/S boundary-specific several key cell cycle regulators, namely cyclin $\mathrm{E}$, cyclin D, cyclin $\mathrm{H}, \mathrm{CDK} 2, \mathrm{CDC} 25 \mathrm{~A}, \mathrm{p} 21$ and p27, which resulted in severe growth arrest in IFN $\gamma$-treated WISH cells.

\section{Materials and Methods \\ Cell culture and reagents}

WISH cell line (Hayflick, 1961) (ATCC No. CCL 25) was maintained in Dulbecco's Modified Eagle's Medium (DMEM) supplemented with $10 \%$ foetal bovine serum and antibiotics (100 units of penicillin per $\mathrm{ml}$ and $100 \mu \mathrm{g}$ streptomycin per $\mathrm{ml}$ of growth medium). About $10^{5} \mathrm{WISH}$

*Corresponding author: Parthasarathi Ajitkumar, Department of Microbiology and Cell Biology, Indian Institute of Science, Bangalore-560012, Karnataka, India; Tel: 91-80-22932344; Fax: 91-80-23602697; E-mail: ajit@mcbl.iisc.ernet.in

Received September 23, 2010; Accepted November 02, 2010; Published November 02, 2010

Citation: Vashistha S, Ajitkumar P (2011) Exposure to Interferon $\gamma$ Decreases Levels and Activity of Key Cell Cycle Proteins Resulting in Severe Growth Arrest of the Human Non-Transformed Cell Line, WISH. J Cancer Sci Ther 3: 013-019. doi:10.4172/1948-5956.1000050

Copyright: (C) 2011 Vashistha S, et al. This is an open-access article distributed under the terms of the Creative Commons Attribution License, which permits unrestricted use, distribution, and reproduction in any medium, provided the original author and source are credited. 
cells per $\mathrm{ml}$ were seeded in a 96-well plate and exposed to 200 units per $\mathrm{ml}$ of human recombinant IFN $\gamma$ (kind gift from Sidney Pestka and Gianni Garotta) for 72 hrs. Viable cell counts were taken once every 12 hrs or once every 24 hrs, upto 72 hrs, in triplicates using trypan blue dye exclusion method. Experimental variations were always less than $10 \%$. For flow cytometry, WISH cells were cultured in the presence of IFN $\gamma$ for 72 hrs. IFN $\gamma$ was washed off and single cell suspensions were prepared. Control cells were cultured identically but without IFN $\gamma$. Cells were fixed at 72 hrs after IFN treatment, stained with propidium iodide and analysed using flow cytometry.

\section{Western blotting}

Cells were suspended in lysis buffer $[50 \mathrm{mM}$ Hepes- $\mathrm{NaOH}(\mathrm{pH}$ 7.4), $150 \mathrm{mM} \mathrm{NaCl}, 1 \mathrm{mM}$ EDTA, $2.5 \mathrm{mM}$ EGTA, $10 \%$ glycerol, 1 mM DTT, $1 \%$ Triton X-100, $25 \mathrm{mM}$ sodium fluoride, $1 \mathrm{mM}$ sodium vanadate, $100 \mathrm{mM} \beta$-glycerophosphate and protease inhibitors (1 $\mu \mathrm{g} / \mathrm{ml}$ each final concentration), aprotinin, leupeptin and pepstatin and pefabloc (100 $\mu \mathrm{g} / \mathrm{ml}$ final concentration)]. The cells were mildly sonicated, the lysate was centrifuged at $10,000 \mathrm{rpm}$ for $10 \mathrm{~min}$ at $4^{\circ} \mathrm{C}$ and protein concentration was determined. Samples containing 100 $\mu \mathrm{g}$ equivalent total protein were fractionated on a $10 \%$ or $12 \%$ SDSPAGE and transferred onto PVDF membrane. After blocking for 2 hrs, the membrane was incubated independently with antibodies. The antibodies were used at the following dilutions: CDK2 (1:1000), CDK4 (1:1000), CDC25A (1:1000), cyclin E (1:500;), cyclin A (1:1000), cyclin D (1:1000), p21 (1:500), p27 (1:1000), IRF1 (1:500), STAT1 $\alpha$ (1:500), CDK7 (1:1000), or cyclin $\mathrm{H}$ (1:500) (all the reagents were gifts from Srikumar Chellappan, Dhan Kalvakolanu, or purchased from Santa Cruz Biotechnology) for one hr, followed by one hr incubation with HRP-conjugated donkey anti-rabbit or sheep anti-mouse secondary antibody $(1: 10,000)$. Signals were visualised using ECL system. Western blotting was repeated thrice with protein preparations from three independent samples. Equal loading was verified by staining the membrane blots with Ponceau S stain. ImageGauge version 2.54 was used to quantitate protein bands.

\section{Immunoprecipitation}

Immunoprecipitations were performed by incubating $200 \mu \mathrm{g}$ (in the case of CDK2 and cyclin E) or $500 \mu \mathrm{g}$ (in the case of CDC25A) of whole cell lysate with $500 \mathrm{ng}$ each of anti-CDK2 or anti-cyclin $\mathrm{E}$ antibodies, or $1 \mu \mathrm{g}$ of anti-CDC25A antibody in $500 \mu \mathrm{l}$ of the lysis buffer overnight at $4^{\circ} \mathrm{C}$. Immune complexes were allowed to adsorb for 2 hrs at $4^{\circ} \mathrm{C}$ onto $30 \mu \mathrm{l}$ of $50 \%$ slurry of protein A-sepharose beads, which were pre-equilibrated in $500 \mu \mathrm{l}$ of lysis buffer for one hr at $4^{\circ} \mathrm{C}$. The beads were washed thrice with lysis buffer and processed for the kinase assay or the phosphatase assay. The immunoprecipitation experiments were carried out thrice with independent sample preparations.

\section{Cyclin dependent kinase 2 assay}

Immunoprecipitated complexes using anti-Cyclin E or anti-CDK2 antibodies were washed with lysis buffer and subsequently with the reaction buffer $[25 \mathrm{mM}$ Hepes- $\mathrm{NaOH}$ (pH 7.4), $25 \mathrm{mM} \mathrm{MgCl}$, $2 \mathrm{mM}$ DTT, $25 \mathrm{mM}$ sodium fluoride, $1 \mathrm{mM}$ sodium vanadate, 100 $\mathrm{mM} \beta$-glycerophosphate and protease inhibitor $(1 \mu \mathrm{g} / \mathrm{ml}$ each final concentration) cocktail containing aprotinin, leupeptin and pepstatin and pefabloc $(100 \mu \mathrm{g} / \mathrm{ml}$ final concentration)]. The beads were resuspended in $30 \mu \mathrm{l}$ of kinase assay mixture [reaction buffer, $25 \mu \mathrm{M}$ $\left({ }^{-32} \mathrm{P}\right)$ ATP and $2 \mu \mathrm{g}$ histone $\mathrm{H} 1$ ], incubated at $37^{\circ} \mathrm{C}$ for $30 \mathrm{~min}$ and the reaction was stopped with SDS-PAGE buffer. The phosphorylated histone protein was run on $12 \%$ SDS-PAGE, gel was dried and the radiolabelled histone was quantitated by phosphorimager analysis. The assay was repeated thrice with three independent samples.

\section{CDC25A phosphatase assay}

The CDC25A phosphatase assay was carried out as described (Jaspers and Miller, 1991). In brief, the CDC25A immunoprecipitates on protein A-sepharose beads were washed extensively with lysis buffer, followed by three washes with phosphatase buffer $[25 \mathrm{mM}$ Hepes- $\mathrm{NaOH}$ ( $\mathrm{pH} 7.4$ ), containing $5 \mathrm{mM}$ EDTA, $2 \mathrm{mM}$ spermidine and $2 \mathrm{mM}$ DTT]. Subsequently, the beads were suspended in phosphatase assay buffer [25 mM Hepes- $\mathrm{NaOH}$ (pH 7.4), $50 \mathrm{mM}$ 2-mercaptoethanol and $0.1 \mathrm{mg} / \mathrm{ml} \mathrm{BSA]}$ and incubated in the presence of $10 \mathrm{mM}$ paranitrophenyl phosphate (pNPP, Sigma) at $30^{\circ} \mathrm{C}$ for $10 \mathrm{~min}$. The reaction was stopped with $800 \mu \mathrm{l}$ of $0.2 \mathrm{M} \mathrm{NaOH}$ and the para-nitrophenol (pNP) formed was measured at $410 \mathrm{~nm}$ and the total $\mu$ moles of pNP formed were calculated. The assay was repeated atleast thrice with three independent sample preparations.

\section{Results}

\section{IFN $\gamma$-induced growth inhibition involved functional STAT1 $\alpha$}

Proliferation of WISH cells was inhibited within the first 12 hrs of exposure to IFN $\gamma$ (Figure 1A), with accumulation of the cells in G1 phase of cell cycle (Figure 1B), as reported earlier by us (Supriya et al., 1998; Vashistha et al., 2007). Induction of STAT1 $\alpha$, upto a level

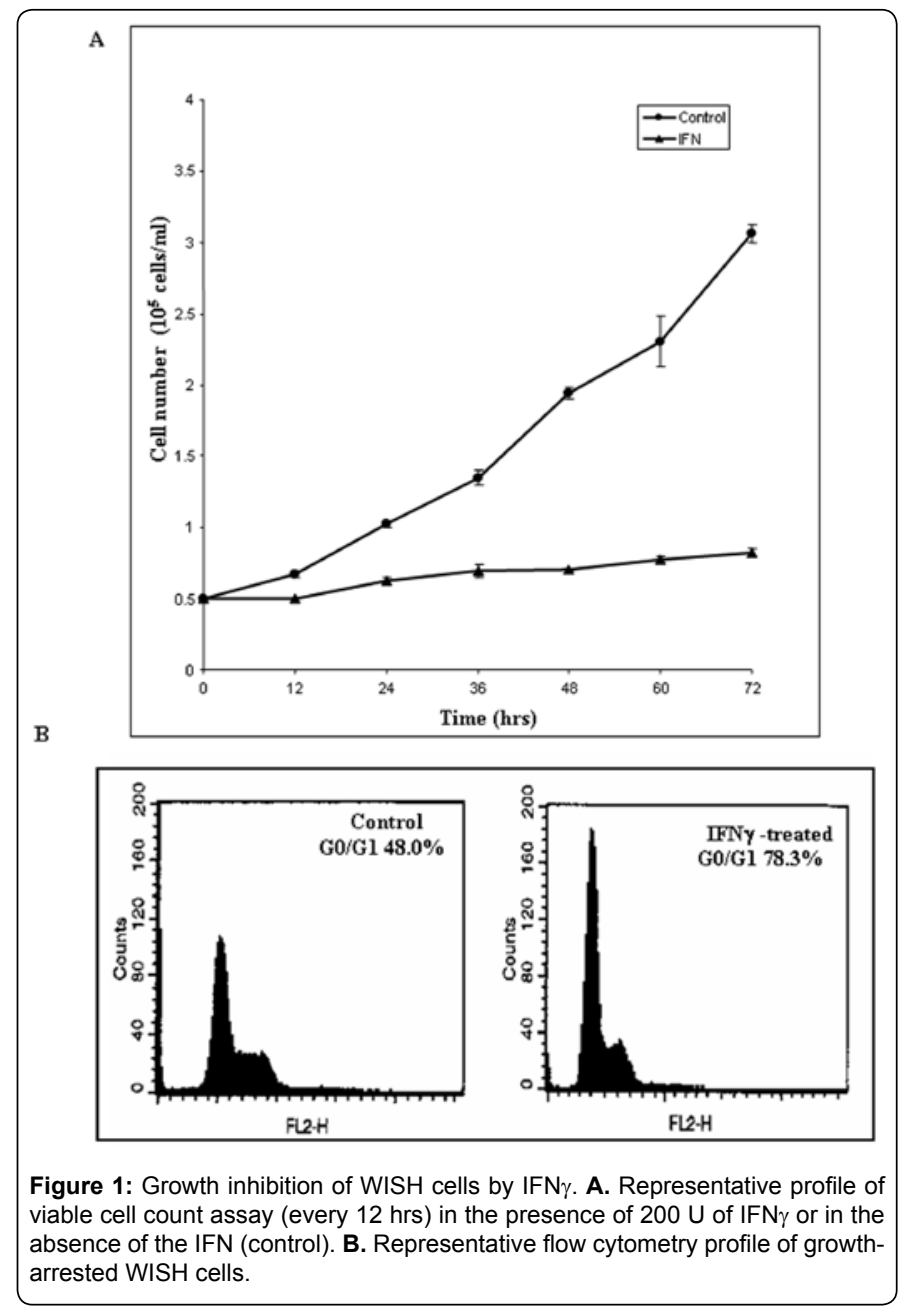




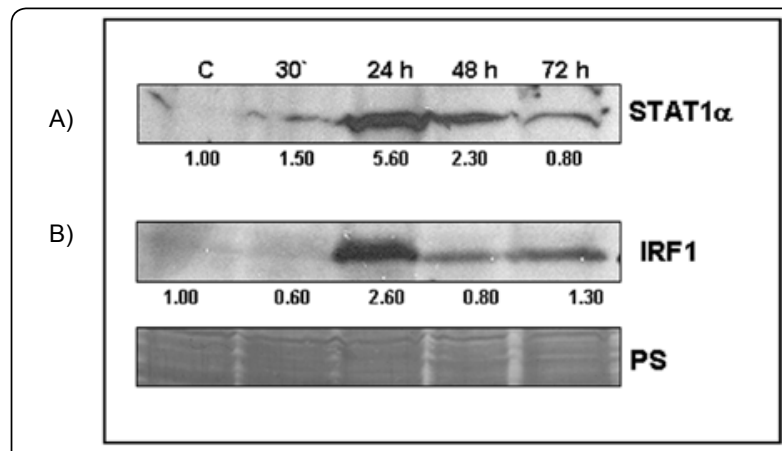

Figure 2: Induction of STAT $1 \alpha$ and IRF1 in IFN $\gamma$-treated WISH cells. Western blots for STAT1 $\alpha$ (A) and IRF1 (B) from cells that were either not treated (control) or treated with $200 \mathrm{U}$ of IFN $\gamma$ for $30 \mathrm{~min}, 24 \mathrm{hrs}, 48 \mathrm{hrs}$ or $72 \mathrm{hrs}$. The densitometry values (indicated below respective lanes) for the samples in the representative blots were normalised with respect to the control. Standard error values for multiple independent experiments were $\pm 5 \%$ and $\pm 8 \%$ respectively. PS: Ponceau S stained gel representing equal loading.

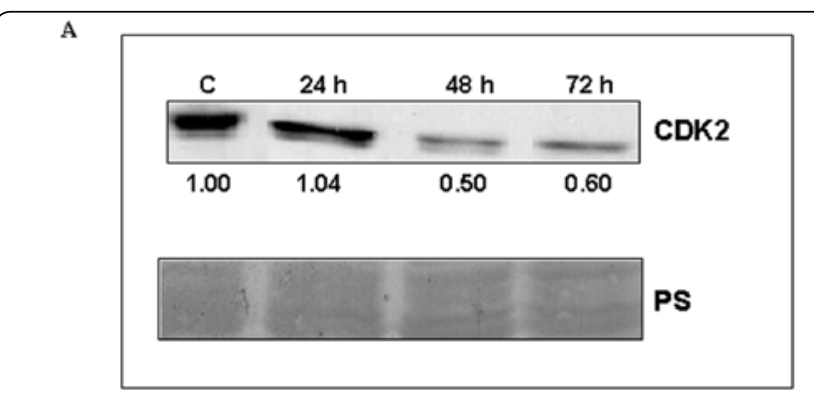

B

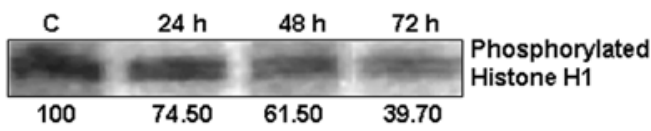

C

\begin{tabular}{|c|c|c|c|c|}
\hline C & $24 \mathrm{~h}$ & $48 \mathrm{~h}$ & $72 \mathrm{~h}$ & \\
\hline & & & & $\begin{array}{l}\text { Phosphorylated } \\
\text { Histone } \mathrm{H} 1\end{array}$ \\
\hline 100 & 28.40 & 20.00 & 50.20 & \\
\hline
\end{tabular}

Figure 3: Protein and activity profiles of CDK2 in WISH cells treated with IFN $\gamma$. WISH cells were either not treated (control) or treated with $200 \mathrm{U}$ of IFN $\gamma$ for 24 hrs, $48 \mathrm{hrs}$ or $72 \mathrm{hrs}$ and the whole cell lysates were: western blotted for CDK2 (A), or assayed for total CDK2 activity (B) or cyclin E-CDK2 activity (C). The densitometry values (indicated below respective lanes) for the treated samples in the representative blots/assays were normalised with respect to the control. Standard error for multiple independent experiments was $\pm 10 \%$. PS: Ponceau S stained gel representing equal loading.

of 1.5-fold of the levels in the untreated cells, could be observed in WISH cells as early as $30 \mathrm{~min}$ post-treatment (Figure 2A), with the levels peaking to 5.6-fold at 24 hrs post-treatment. An increase in the levels of interferon regulatory factor 1 (IRF1), which is one of the primary response genes (Harada et al., 1994; Pine et al., 1990; Sims et al., 1993; Lallemand et al., 1997), peaking to 2.6-fold at 24 hrs post-treatment indicated that STAT $1 \alpha$, which was induced in response to IFN treatment, was functionally active (Figure 2B). The same fold of IRF1 induction could also be observed as early as 9 hrs post-treatment as well (data not shown).

\section{Levels and/or activity of cyclin E-CDK2, cyclin E and cyclin A}

The levels of total CDK2, the regulatory kinase governing G1/S transition (Koff et al., 1992; Dulic et al., 1992; Tsai et al., 1993), were found to steadily decline to about $50 \%$ of the control sample by 48 hrs of IFN treatment, which then stabilised upto 72 hrs of treatment (Figure 3A and Table 1). In vitro assay for the activity of total CDK2 revealed a decline to $74.5 \%$ of the untreated cells at $24^{\text {th }}$ hr of treatment, which steadily decreased further to $61.5 \%$ by $48^{\text {th }} \mathrm{hr}$ and to $39.7 \%$ by the end of 72 hrs of treatment (Figure 3B). Activity status of cyclin E-CDK2 complex (the active form of CDK2 during G1/S transition) in WISH cells detained by IFN $\gamma$ showed severe reduction to $28.4 \%$ and further to $20 \%$ of the control sample by the end of $24^{\text {th }}$ hr and $48^{\text {th }} \mathrm{hr}$ respectively, with partial recovery to only $50.2 \%$ of the control sample by the end of 72 hrs of exposure (Figure 3C).

\begin{tabular}{|l|l|l|l|}
\hline $\begin{array}{l}\text { Name of the cell } \\
\text { cycle- } \\
\text { regulated protein }\end{array}$ & \multicolumn{4}{|l|}{$\begin{array}{l}\text { Per cent level of the protein with respect } \\
\text { [Duration of treatment with IFNy (hrs)] to control }\end{array}$} \\
\hline & {$[24]$} & {$[48]$} & {$[72]$} \\
\hline CDK2 & 100 & 50 & 50 \\
\hline Cyclin E & 50 & 10 & 20 \\
\hline Cyclin A & 50 & 80 & 30 \\
\hline Cyclin H & 90 & 40 & 50 \\
\hline CDK7 & 80 & 120 & 140 \\
\hline CDC25A & 120 & 90 & 50 \\
\hline p21 & 60 & 40 & 10 \\
\hline p27 & 80 & 50 & 02 \\
\hline Cyclin D & 80 & 10 & 20 \\
\hline CDK4 & 90 & 90 & 80 \\
\hline
\end{tabular}

The total lysates from the cells, which were treated with IFN $\gamma$ for different duration, were fractionated on SDS-PAGE, western blotted for the cell cycle-regulated proteins with respective antibody and the levels of the protein in the blots were quantitated using ImageGauge version 2.54

Table 1: Summary of the changes in the levels of cell cycle-regulated proteins with respect to time (post-treatment with IFN $\gamma$ ).

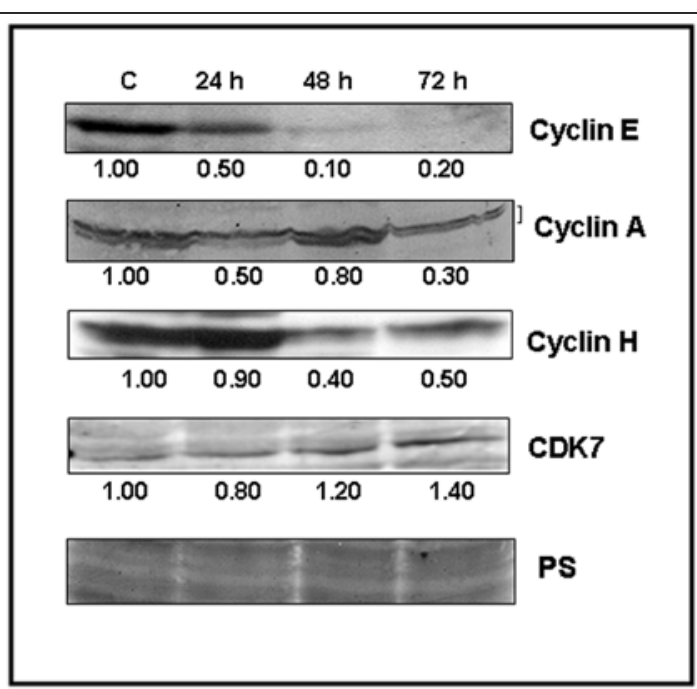

Figure 4: Western blot of the protein profiles of cyclin $\mathrm{E}$, cyclin $\mathrm{A}$, cyclin $\mathrm{H}$ and CDK7. WISH cells were either not treated (control) or treated with $200 \mathrm{U}$ of IFN $\gamma$ for $24 \mathrm{hrs}, 48 \mathrm{hrs}$ or $72 \mathrm{hrs}$ and the whole cell lysates were western blotted for: cyclin E, Cyclin A, cyclin $\mathrm{H}$ and CDK7. The densitometry values (indicated below respective lanes) for the treated samples in the representative blots were normalised with respect to the control. Standard error values for multiple independent experiments were $\pm 9-13 \%$ for different proteins. PS: Ponceau S stained gel representing equal loading. 
A

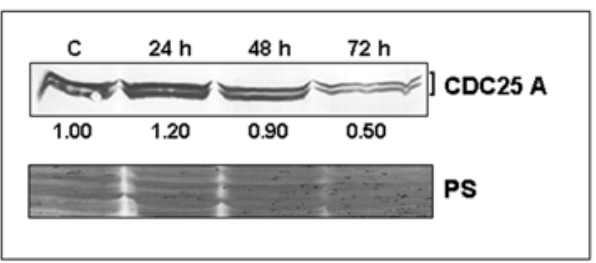

B

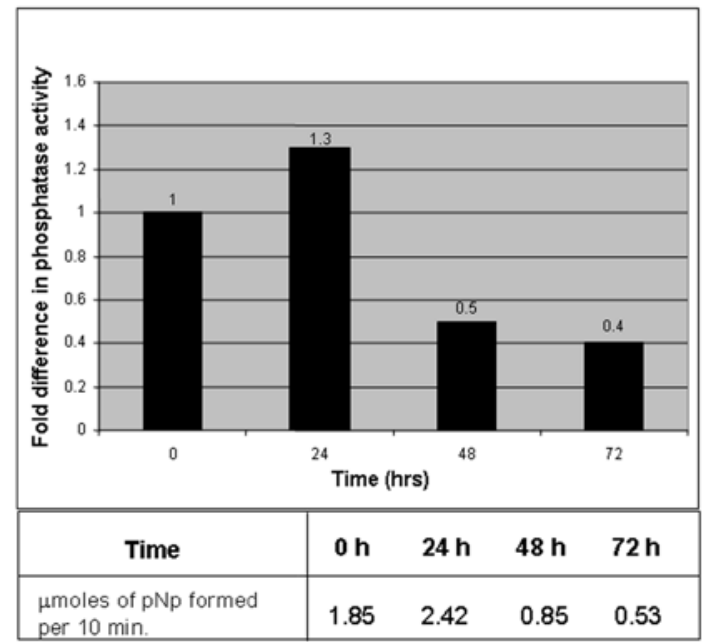

Figure 5: Protein and activity profiles of CDC25A. WISH cells were either not treated (control) or treated with $200 \mathrm{U}$ of IFN $\gamma$ for $24 \mathrm{hrs,} 48 \mathrm{hrs}$ or $72 \mathrm{hrs}$ and the whole cell lysates (200 $\mu \mathrm{g}$ each) were: western blotted for CDC25A phosphatase (A) or assayed for CDC25A phosphatase activity (B). The densitometry values (indicated below respective lanes in the western blot) for the treated samples in the representative blot/assay have been normalised with respect to the control. The activity in the Table below is represented in terms of $\mu$ moles of pNP formed per $10 \mathrm{~min}$. The fold difference in the phosphatase activity was normalised with respect to the control. Standard error for multiple independent experiments was $\pm 10 \%$. PS: Ponceau S stained gel representing equal loading.

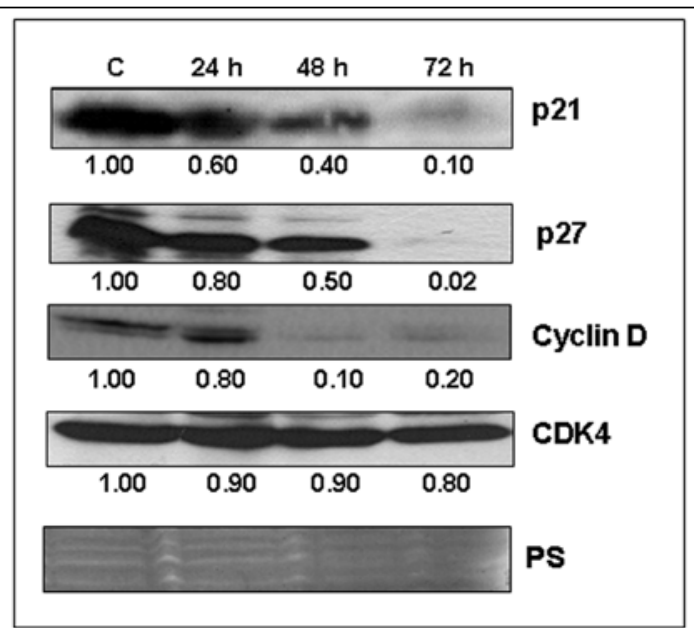

Figure 6: Western blot of the protein profiles of p21, p27, cyclin D and CDK4 in WISH cells treated with IFN $\gamma$. WISH cells were either not treated (control) or treated with $200 \mathrm{U}$ of IFN $\gamma$ for $24 \mathrm{hrs}, 48 \mathrm{hrs}$ or $72 \mathrm{hrs}$ and the whole cell lysates were western blotted for: p21, p27, cyclin D and CDK4. The densitometry values (indicated below respective lanes) for the treated samples in the representative blots were normalised with respect to the control. Standard error values for multiple independent experiments were $\pm 4-8 \%$ for different proteins. PS: Ponceau $S$ stained gel representing equal loading.

Since cyclin $\mathrm{E}$ is required for the formation of active cyclin E-CDK2 complex (Dulic et al., 1992), low levels of cyclin E component and thereby its nonavailability in required quantity to form cyclin E-CDK2 complex could be a reason for the decline of cyclin E-CDK2 activity. In fact, the levels of cyclin E showed a steep decline to $50 \%$ of the control by the $24^{\text {th }} \mathrm{hr}$ of IFN $\gamma$ treatment and thereafter to about $10 \%$ and $20 \%$ of the control sample by the $48^{\text {th }}$ and $72^{\text {nd }}$ hr of treatment respectively (Figure 4 and Table 1). Thus, one of the possible reasons for the low levels of cyclin E-CDK2 activity, which might have caused proliferation arrest of WISH cells, could be the absence of required quantity of cyclin $\mathrm{E}$ to form an active cyclin E-CDK2 complex to enable G1/S transition.

Further, cyclin $\mathrm{A}$ is required for the onset of DNA replication in early S phase (Girard et al., 1991; Pagano et al., 1992; Zindy et al., 1992; Rosenblatt et al., 1992) through the formation of active cyclin A-CDK2 complex (Connell-Crowley et al., 1993). Therefore, lack of required quantity of cyclin $\mathrm{A}$ would also induce detention of cells prior to DNA synthesis. In WISH cells exposed to IFN $\gamma$, the levels of cyclin A initially declined to $50 \%$ of the control cells by the $24^{\text {th }} \mathrm{hr}$ of treatment (Figure 4 and Table 1), by which time growth inhibition had already occurred as revealed by viable cell count assay (Figure 1A). However, unlike cyclin E, subsequently it showed recovery to $80 \%$ of the control by the $48^{\text {th }} \mathrm{hr}$ of exposure, but followed by a decline to $30 \%$ of the control by the $72^{\text {nd }} \mathrm{hr}$ of exposure (Figure 4 and Table 1). At present, we do not have an explanation for the repeatedly and consistently observed cyclic pattern of cyclin-A levels in IFN $\gamma$-treated WISH cells.

\section{Levels and/or activity of CAKII and CDC25A}

One of the other possibilities for the low activity of cyclin E-CDK2 could be the absence of activating phosphorylation on T160 residue of CDK2 by CDK2 activating kinase II (CAKII) (Gu et al., 1992), which is a complex of CDK7 and cyclin $\mathrm{H}$ (Poon et al., 1993; Fisher and Morgan, 1994; Kim et al., 1996). Nevertheless, the levels of cyclin $\mathrm{H}$ and CDK7 were largely unaffected upto $24 \mathrm{hrs}$ of IFN treatment (Figure 4 and Table 1), by which time the cells had already undergone cell cycle arrest ( $12^{\text {th }} \mathrm{hr}$ itself; see Figure $\left.1 \mathrm{~A}\right)$, thereby ruling out the immediate contribution of cyclin H-CDK7 complex in compromising the activity of CDK2. Yet another possibility for the reduced activity of CDK2 could be the lack of activation of CDK2, owing to the lack of dephosphorylation of T14 and Y15 residues by CDC25A phosphatase (Gu et al., 1992; Gabrielli et al., 1992). The activation of CDC25A phosphatase itself is regulated by a cyclin E-CDK2 dependent phosphorylation during the G1/S transition, as part of an auto-amplification loop (Hoffmann et al., 1994). Thus, it is likely that CDC25A phosphatase itself might be inactive in IFN $\gamma$-arrested WISH cells that exhibited low levels of cyclin E-CDK2 activity.

However, CDC25A protein levels were maintained upto 48 hrs (Figure 5A and Table 1). Notably, the activity of CDC25A also did not show reduction at $24^{\text {th }} \mathrm{hr}$, by which time (12 hrs before itself) the cells were already growth-inhibited. In fact, it showed a marginal but repeatedly consistent increase of about $30 \%$ over that of control. Subsequently, the activity steadily declined to $46 \%$ and further to $29 \%$ of the control by the $48^{\text {th }}$ and $72^{\text {nd }}$ hr of treatment respectively (Figure $5 \mathrm{~B}$ and Table 1). Thus, the protein levels and activity of CDC25A were maintained, if not showed a slight consistent increase at $24^{\text {th }}$ $\mathrm{hr}$, when cyclin E-CDK2 activity had already decreased to $28.4 \%$. It suggested that CDC25A phosphatase activity was not affected atleast till $24^{\text {th }} \mathrm{hr}$ by the decline of activity of cyclin E-CDK2 in IFN $\gamma$-treated WISH cells. However, one of the possibilities for the decrease in the activity of CDC25A at $48^{\text {th }}$ and $72^{\text {nd }}$ hrs of exposure could be lack of activation of the phosphatase. This might be due to the lack of 
activating phosphorylation on the phosphatase by cyclin E-CDK2 as part of the autoamplification loop (Hoffmann et al., 1994), owing to insufficient levels of active cyclin E-CDK2 at these time points. The steep decline in cyclin E-CDK2 activity to $10-20 \%$ subsequent to $24^{\text {th }}$ and $48^{\text {th }} \mathrm{hr}$ of exposure supports this possibility.

\section{Levels of p21, p27, cyclin D and CDK4}

The CDK inhibitors p21 and p27 are known to inhibit CDK2 activity of cyclin E-CDK2 complex by physical association with the complex (Aprelikova et al., 1995; Sheaff et al., 1997; Morisaki et al., 1997; Sherr and Roberts, 1999; Xu et al., 1999). Proliferation arrest induced by IFN $\gamma$ has often been accompanied by an increase in the levels of p21, with concomitant reduction in CDK2 activity in different cell systems (Chin et al., 1996; Kominsky et al., 1998; Xaus et al., 1999; Gooch et al., 2000). However, contrary to these findings, the levels of p21 as well as of p27 were found to be low in IFN $\gamma$-induced cell cycle arrested WISH cells. Between the two CDK inhibitors, p21 was more severely affected with its levels dropping to $60 \%$, to $40 \%$ and on to $10 \%$ of the control sample at $24^{\text {th }}, 48^{\text {th }}$ and $72^{\text {nd }} \mathrm{hr}$ of treatment respectively (Figure 6 and Table 1). The levels of p27 reduced to $80 \%$, to $50 \%$ and to $2 \%$ at these time points of IFN treatment (Figure 6 and Table 1). Absence of any up regulation in the levels of p21 and p27 suggested that these CDKI proteins have not contributed to the reduced cyclin E-CDK2 activity observed in the cell cycle arrest induced by IFN $\gamma$ in WISH cells.

Since active cyclin D-CDK4 complex is required for $\mathrm{G} 1$ progression (Baldin et al., 1993; Tam et al., 1994; Sherr et al., 1994), reduction in the levels and/or activity of cyclin D-CDK4, if induced by IFN $\gamma$, could effect cell cycle arrest in G1 phase. However, the levels of cyclin D were maintained at about $80 \%$ of the control at $24^{\text {th }} \mathrm{hr}$ of exposure to the IFN, subsequently declining to $10 \%$ of the control by the $48^{\text {th }}$ hr and to $20 \%$ of the control by the $72^{\text {nd }}$ hr of treatment (Figure 6 and Table 1). On the contrary, levels of the cognate kinase CDK4 remained unaffected throughout the 72 hrs of exposure to IFN $\gamma$ (Figure 6 and Table 1).

\section{Discussion}

In the present study, among the panel of molecular changes observed in the IFN $\gamma$-induced growth-arrested WISH cells, the most striking one was the dramatic decline in the activity of cyclin E-CDK2, with the concomitant reduction in cyclin E levels to $50 \%$ by the $24^{\text {th }} \mathrm{hr}$ and eventually to barely detectable levels. This indicated the possible non-availability of cyclin $\mathrm{E}$ for the formation of an active cyclin E-CDK2 complex, thereby causing cell cycle arrest. However, cyclin E synthesis is known to occur only during late G1 and prior to which cyclin E levels are undetectably low (Ohtsubo et al., 1995). Nevertheless, in silico analysis of about $5 \mathrm{~kb}$ region upstream of cyclin $\mathrm{E}$ open reading frame revealed the presence of a putative consensus IRF1 binding sequence ATAAATGGAAACT (the consensus sequence being G/A AAA G/C T/C GAAA G/C T/C; Taniguchi et al., 1997) at nucleotide position -2963 to -2951 . Therefore, although the consensus IRF1 binding sequence is far upstream of cyclin E open reading frame, an IRF1-dependent repression of cyclin E promoter cannot be ruled out. Induction of IRF1 transfectants of NIH 3T3 fibroblast cells was found to downregulate cdk2 gene expression by interfering with Sp1-dependent transcriptional activation of cdk2 promoter, resulting in severe decline of CDK2 levels within 8 hrs of induction (Xie et al., 2003). In similar lines, an IRF1-mediated interference of Sp1dependent transcription of cyclin E promoter, as observed in the case of transcriptional downregulation of cdk2 promoter by IFN $\gamma$
(Xie et al., 2003), cannot also be ruled out as Sp1 binding sites (the consensus sequence being AGGGCGGGGC, Shiffman et al., 1996) are present at nucleotide positions -491 to -482 (GGGGCGGGGT), -865 to -856 (GGGGCGGGGC) and -1264 to 1255 (GGGGCGGGGA). Although CDK2 levels were stable at $24^{\text {th }} \mathrm{hr}$ and declined only at $48^{\text {th }} \mathrm{hr}$ of exposure, in spite of IRF1 levels peaking to 2.6 -fold as early as $9^{\text {th }} \mathrm{hr}$ of exposure to the IFN (data not shown) and being maintained at the level upto $24^{\text {th }} \mathrm{hr}$, it is possible that the $50 \%$ levels of CDK2 may not be sufficient to take cell cycle progression forward, owing to the low levels of cyclin E. Above all, the activity of cyclin E-CDK2 complex was also found to decrease steadily in response to IFN $\gamma$ treatment.

The pattern of gradual decline in the total CDK2 activity in growth-arrested WISH cells $\left(74.5 \%\right.$ at $24^{\text {th }} \mathrm{hr}, 61.5 \%$ at $48^{\text {th }} \mathrm{hr}$ and $39.7 \%$ at $72 \mathrm{hr}$ post-treatment) is in contrast to the sudden inhibition of total CDK2 activity, as early as within 6 hrs of exposure to the IFN $\gamma$, in growth-arrested mouse embryonic fibroblast cell line and Stat 1 transfectant of Stat1-null U3A cells (Bromberg et al., 1996) and glioblastoma cell lines T98G, SNB-19 and U-373 (Kominsky et al., 1998). However, in these cell lines, in spite of the reduction in total CDK2 activity, the levels of CDK2 were found to remain unaffected. In growth-arrested WISH cells, in spite of the decline in cyclin E levels, the maintenance of total CDK2 activity at $74.5 \%$ and $61.5 \%$ at $24^{\text {th }}$ and $48^{\text {th }}$ hrs of exposure might be due to a probable association of CDK2 with cyclin A, whose levels were maintained at $50 \%$ and $80 \%$ at $24^{\text {th }}$ and $48^{\text {th }}$ hrs of exposure. However, we have not verified this possibility. However, it is possible that the sharp decline in its levels within 24 hrs post-IFN $\gamma$ treatment might be low enough to maintain G1/S arrest of WISH cells induced by low activity of cyclin E-CDK2. In contrast to the slow turnover of cyclin A in WISH cells, IFN $\gamma$ treatment had been found to drastically inhibit cyclin A transcription by as early as 12-24 hrs of exposure in vascular smooth muscle cells (Sibinga et al., 1999) and human mammary epithelial cells (Harvat and Jetten, 1996). However, unlike in WISH cells, the levels of CDK2 and cyclin E remained more or less unaffected in these cells.

Downregulation of cyclin $\mathrm{D}$ expression has been found to occur in murine bone marrow-derived macrophages within 24 hrs of exposure to IFN $\gamma$ (Cocks et al., 1992). However, in contrast to this observation, cyclin D was found upregulated to a level of 3.8-fold in vascular smooth muscle cells exposed to IFN $\gamma$ (Sibinga et al., 1999). Unlike in these cell systems, in growth-arrested WISH cells, the levels of cyclin $\mathrm{D}$ (and of CDK4) were maintained at the $24^{\text {th }} \mathrm{hr}$ of exposure, by which time the cells had already suffered growth arrest (by the $12^{\text {th }} \mathrm{hr}$ of exposure). The decline in cyclin D levels at the $48^{\text {th }}$ and $72^{\text {nd }}$ hrs of exposure might possibly be reflective of the cyclin turnover, as the cyclin was no more required for $\mathrm{G} 1$ progression owing to inhibition of cell cycle progression. This suggested that involvement of cyclin D and/or of cyclin D-CDK4 complex was unlikely in the cell cycle arrest of WISH cells by IFN $\gamma$. Therefore, the activity status of cyclin D-CDK4 complex was not examined.

IFN $\gamma$-specific induction of IRF1 has also been found to favour apoptosis through the induction of caspase 8 by IRF1 (Fulda and Debatin, 2002). In addition, reduced levels of $\mathrm{p} 21$ have been reported to lead to apoptosis or sensitise human hepatocellular carcinoma cells (Detjen et al., 2003), human breast cancer (Fan et al., 2003) and human colon cancer (Tian et al., 2000) towards apoptosis. However, contrary to these studies, in growth-arrested WISH cells, neither the sharp decline in p21 levels (to 10\%) nor the 2.6-fold increase in IRF1 levels triggered apoptosis even after $72 \mathrm{hrs}$ of treatment with IFN $\gamma$ (data not shown). In our studies, the phosphorylation status of Rb was 
Citation: Vashistha S, Ajitkumar P (2011) Exposure to Interferon $\gamma$ Decreases Levels and Activity of Key Cell Cycle Proteins Resulting in Severe Growth Arrest of the Human Non-Transformed Cell Line, WISH. J Cancer Sci Ther 3: 013-019. doi:10.4172/1948-5956.1000050

not found to exhibit a specific pattern (data not shown) disallowing us to comment on any specific contribution of Rb to IFN-mediated cell cycle arrest of WISH cells.

Thus, taken together, considering the presence of IRF1 binding consensus site upstream of cyclin E gene, Sp1 binding site upstream of cdk2 gene for interference by IRF1, steady decrease in the steady state levels of cyclin E $(50 \%, 10 \%$ and $20 \%)$ and of CDK2 $(100 \%, 50 \%$ and $50 \%$ ) (Table 1) and steady decrease in the activity of cyclin E-CDK2 complex, it may be suggested that growth arrest of WISH cells occurred due to downregulation of cyclin $\mathrm{E}$ and cdk2 genes. The low levels of cyclin E and CDK2 would have resulted in the low levels of cyclin E-CDK2 complex and thereby low levels of active cyclin E-CDK2 complex, leading to arrest of cell cycle progression. Since the active cyclin E-CDK2 complex is required for progression of cell cycle through G1/S boundary, these observations are in concurrence with our earlier findings that IFN $\gamma$ detains WISH cells at G1/S boundary by effecting growth-arrest in late G1 phase (Supriya et al., 1998; Vashistha et al., 2007). The molecular mechanisms that lead to the down regulation of the levels of cyclin $\mathrm{E}$ require further detailed investigations.

\section{Acknowledgements}

Authors thank Dr. Srikumar Chellappan and Dr. Dhan Kolvakolanu for the antibodies against some of the cell cycle proteins. Authors are indebted to Sidney Pestka and Gianni Garotta for the free gift of recombinant human interferon $\gamma$, during the early part of this study. The study was supported by DST grant Nos. SP/ SO/B15/90 and SP/SO/D-60/98.

\section{References}

1. Aharon M, Dvilansky A, Shpilberg O, Nathan I (2002) Involvement of proteases in the action of IFN-gamma on WISH cells. J Interferon Cytokine Res 22: 847852.

2. Aprelikova O, Xiong Y, Liu ET (1995) Both p16 and p21 families of cyclindependent kinase (CDK) inhibitors block the phosphorylation of cyclindependent kinases by the CDK-activating kinase. J Biol Chem 270: 1819518207.

3. Baldin V, Lukas J, Marcote MJ, Pagano M, Draetta G (1993) Cyclin D1 is a nuclear protein required for cell cycle progression in G1. Genes Dev 7: 812821.

4. Bromberg JF, Horvath CM, Wen Z, Schreiber RD, Darnell JE (1996) Transcriptionally active Stat 1 is required for the antiproliferative effects of both interferon alpha and interferon gamma. Proc Natl Acad Sci USA 93: 7673-7678.

5. Chin YE, Kitagawa M, Su WC, You ZH, Iwamoto Y, et al. (1996) Cell growth arrest and induction of cyclin-dependent kinase inhibitor p21 WAF1/CIP1 mediated by STAT1. Science 272: 719-722.

6. Cocks BG, Vairo G, Bodrug SE, Hamilton JA (1992) Suppression of growth factor-induced CYL1 cyclin gene expression by antiproliferative agents. J Biol Chem 267: 12307-12310.

7. Connell-Crowley L, Solomon MJ, Wei N, Harper JW (1993) Phosphorylation independent activation of human cyclin-dependent kinase 2 by cyclin $\mathrm{A}$ in vitro. Mol Biol Cell 4: 79-92.

8. Darnell JE, Kerr IM, Stark GR (1994) Jak-STAT pathways and transcriptional activation in response to IFNs and other extracellular signaling proteins. Science 264: 1415-1421.

9. Detjen KM, Murphy D, Welzel M, Farwig K, Wiedenmann B, et al. (2003) Downregulation of p21(waf/cip-1) mediates apoptosis of human hepatocellula carcinoma cells in response to interferon-gamma. Exp Cell Res 282: 78-89.

10. Dulic V, Lees E, Reed SI (1992) Association of human cyclin E with a periodic G1-S phase protein kinase. Science 257: 1958-1961.

11. Fan $\mathrm{Y}$, Borowsky AD, Weiss RH (2003) An antisense oligodeoxynucleotide to p21 (Waf1/Cip1) causes apoptosis in human breast cancer cells. Mol Cancer Ther 2: 773-782.

12. Fisher RP, Morgan DO (1994) A novel cyclin associates with MO15/CDK7 to form the CDK-activating kinase. Cell 78: 713-724.
13. Fulda S, Debatin KM (2002) IFN-gamma sensitizes for apoptosis by upregulating caspase-8 expression through the Stat1 pathway. Oncogene 21: 2295-2308.

14. Gabrielli BG, Lee MS, Walker DH, Piwnica-Worms H, Maller JL (1992) Cdc25 regulates the phosphorylation and activity of the Xenopus cdk2 protein kinase complex. J Biol Chem 267: 18040-18046.

15. Girard F, Strausfeld U, Fernandez A, Lamb NJ (1991) Cyclin A is required for the onset of DNA replication in mammalian fibroblasts. Cell 67: 1169-1179.

16. Gooch JL, Herrera RE, Yee D (2000) The role of p21 in interferon gammamediated growth inhibition of human breast cancer cells. Cell Growth Differ 11: $335-342$

17. Gu Y, Rosenblatt J, Morgan DO (1992) Cell cycle regulation of CDK2 activity by phosphorylation of Thr160 and Tyr15. EMBO J 11: 3995-4005.

18. Harada H, Takahashi E, Itoh S, Harada K, Hori TA, et al. (1994) Structure and regulation of the human interferon regulatory factor 1 (IRF-1) and IRF-2 genes: implications for a gene network in the interferon system. Mol Cell Biol 14: 15001509.

19. Harvat BL, Jetten AM (1996) Gamma-interferon induces an irreversible growth arrest in mid-G1 in mammary epithelial cells which correlates with a block in hyperphosphorylation of retinoblastoma. Cell Growth Differ 7: 289-300.

20. Hayflick $L$ (1961) The establishment of a line (WISH) of human amnion cells in continuous cultivation. Exp Cell Res 23: 14-20.

21. Hoffmann I, Draetta G, Karsenti E (1994) Activation of the phosphatase activity of human cdc25A by a cdk2-cyclin $\mathrm{E}$ dependent phosphorylation at the G1/S transition. EMBO J 13: 4302-4310.

22. Jaspers SR, Miller TB (1991) Purification and the immunological characterization of rat protein phosphatase $2 \mathrm{~A}$ : enzyme levels in diabetic liver and heart. Mol Cell Biochem 101: 167-174.

23. Kim KK, Chamberlin HM, Morgan DO, Kim SH (1996) Three-dimensiona structure of human cyclin $\mathrm{H}$, a positive regulator of the CDK-activating kinase. Nat Struct Biol 3: 849-855.

24. Koff A, Giordano A, Desai D, Yamashita K, Harper JW, et al. (1992) Formation and activation of a cyclin E-cdk2 complex during the G1 phase of the human cell cycle. Science 257: 1689-1694.

25. Kominsky S, Johnson HM, Bryan G, Tanabe T, Hobeika AC, et al. (1998) IFNgamma inhibition of cell growth in glioblastomas correlates with increased levels of the cyclin dependent kinase inhibitor p21WAF1/CIP1. Oncogene 17: 2973-2979.

26. Lallemand C, Bayat-Sarmadi M, Blanchard B, Tovey MG (1997) Identification of a novel transcriptional regulatory element common to the p53 and interferon regulatory factor 1 genes. J Biol Chem 272: 29801-29809.

27. Mäkelä TP, Tassan JP, Nigg EA, Frutiger S, Hughes GJ, et al. (1994) A cyclin associated with the CDK-activating kinase MO15. Nature 371: 254-257.

28. Morisaki H, Fujimoto A, Ando A, Nagata Y, Ikeda K, et al. (1997) Cell cycledependent phosphorylation of p27 cyclin-dependent kinase (Cdk) inhibitor by cyclin E/Cdk2. Biochem Biophys Res Commun 240: 386-390.

29. Ohtsubo M, Theodoras AM, Schumacher J, Roberts JM, Pagano M (1995) Human cyclin E, a nuclear protein essential for the G1-to-S phase transition. Mol Cell Biol 15: 2612-2624.

30. Pagano M, Pepperkok R, Verde F, Ansorge W, Draetta G (1992) Cyclin A is required at two points in the human cell cycle. EMBO J 11: 961-971.

31. Pestka S, Langer JA, Zoon KC, Samuel CE (1987) Interferons and their actions Annu Rev Biochem 56: 727-777.

32. Pine R, Decker T, Kessler DS, Levy DE, Darnell JE Jr (1990) Purification and cloning of interferon-stimulated gene factor 2 (ISGF2): ISGF2 (IRF-1) can bind to the promoters of both beta interferon- and interferon-stimulated genes but is not a primary transcriptional activator of either. Mol Cell Biol 10: 2448-2457.

33. Poon RY, Yamashita K, Adamczewski JP, Hunt T, Shuttleworth J (1993) The cdc2-related protein $\mathrm{p} 40 \mathrm{MO} 15$ is the catalytic subunit of a protein kinase that can activate p33cdk2 and p34cdc2. EMBO J 12: 3123-3132.

34. Rosenblatt J, Gu Y, Morgan DO (1992) Human cyclin-dependent kinase 2 is activated during the $S$ and $G 2$ phases of the cell cycle and associates with cyclin A. Proc Natl Acad Sci USA 89: 2824-2828.

35. Sheaff RJ, Groudine M, Gordon M, Roberts JM, Clurman BE (1997) Cyclin E-CDK2 is a regulator of p27Kip1. Genes Dev 11: 1464-1478. 
36. Sherr CJ, Kato J, Quelle DE, Matsuoka M, Roussel MF (1994) D-type cyclins and their cyclin-dependent kinases: G1 phase integrators of the mitogenic response. Cold Spring Harb Symp Quant Biol 59: 11-19.

37. Sherr CJ, Roberts, JM (1999) CDK inhibitors: positive and negative regulators of G1-phase progression. Genes Dev 13: 1501-1512.

38. Shiffman D, Brooks EE, Brooks AR, Chan CS, Milner PG (1996) Characterisation of the human cyclin-dependent kinase 2 gene: Promoter analysis and gene structure. J Biol Chem 271: 12199-12204.

39. Sibinga NES, Wang H, Perrella MA, Endege WO, Patterson C, et al. (1999) Interferony-mediated inhibition of cyclin A gene transcription is independent of individual cis-acting elements in the cyclin A promoter. J Biol Chem 274: 1213912146

40. Sims SH, Cha Y, Romine MF, Gao PQ, Gottlieb K, et al. (1993) A novel interferon-inducible domain: structural and functional analysis of the human interferon regulatory factor 1 gene promoter. Mol Cell Biol 13: 690-702.

41. Supriya P, Joshi CV, Ajitkumar $P$ (1998) IFN-gamma inhibits growth of WISH cells in a cell cycle phase-specific manner. J Interferon Cytokine Res 18: 215217.

42. Tam SW, Theodoras AM, Shay JW, Draetta GF, Pagano M (1994) Differential expression and regulation of Cyclin D1 protein in normal and tumor human cells: association with Cdk4 is required for Cyclin D1 function in G1 progression. Oncogene 9: 2663-2674.

43. Taniguchi T, Lamphier MS, Tanaka N (1997) IRF-1: the transcription factor linking the interferon response and oncogenesis. Biochem Biophys Acta 1333: M9-M17.

44. Tian H, Wittmack EK, Jorgensen TJ (2000) p21WAF1/CIP1 antisense therapy radiosensitises human colon cancer by converting growth arrest to apoptosis. Cancer Res 60: 679-684.

45. Tsai LH, Lees E, Faha B, Harlow E, Riabowol K (1993) The cdk2 kinase is required for the G1-to-S transition in mammalian cells. Oncogene 8: 1593 1602

46. Vashistha S, Patil S, Joshi C, Ajitkumar P (2007) Determination of growth inhibitory action point of interferon $\gamma$ on WISH cells in cell cycle progression and the window of responsiveness of the cells to the interferon. Cytokine 37 108-118.

47. Xaus J, Cardo M, Valledor AF, Soler C, Lloberas J, et al. (1999) Interferon gamma induces the expression of p21waf-1 and arrests macrophage cell cycle, preventing induction of apoptosis. Immunity 11: 103-113.

48. Xie RL, Gupta S, Miele A, Shiffman D, Stein JL, et al. (2003) The tumor suppressor interferon regulatory factor 1 interferes with SP1 activation to repress the human CDK2 promoter. J Biol Chem 278: 26589-26596.

49. Xu X, Nakano T, Wick S, Dubay M, Brizuela L (1999) Mechanism of Cdk2 Cyclin E inhibition by p27 and p27 phosphorylation. Biochemistry 38: 87138722.

50. Zindy F, Lamas E, Chenivesse X, Sobczak J, Wang J, et al. (1992) Cyclin A is required in $\mathrm{S}$ phase in normal epithelial cells. Biochem Biophys Res Commun 182: $1144-1154$. 